\title{
Long-term Follow-up of a Feline Solitary Osteochondroma on the Left Mandibular Ramus and Temporomandibular Joint with Surrounding Tissue Treated by Palliative Surgery
}

\author{
左下顎枝、顎関節およびその周囲に発生した孤立性骨軟骨腫に対し \\ 緩和的外科的切除を実施し長期的経過観察を行った猫の一例
}

\author{
Jun MATSUMOTO ${ }^{1,2) *}$, Ayako OKUDA ${ }^{3)}$, Yoshimi UCHIDA ${ }^{1)}$, Naoko OGI ${ }^{1)}$ and Etsuko OGI ${ }^{1)}$ \\ 松本 淳 1,2$) *$ 奥田 綾子 3) 内田 佳美 ${ }^{1)}$ 小儀 直子 1) 小儀 悦子 1) \\ 1) Ogi Animal Hospital, 17-3 Takashiro-cho, Suita-shi, Osaka 564-0024, Japan \\ 2) Ibarakimotomachi Animal Hospital, 6-30 Motomachi, Ibaraki-shi, Osaka 567-0882, Japan \\ 3) Vettec Dentistry, 3-20-7 Higashimukojima, Sumida, Tokyo 131-0032, Japan
}

\begin{abstract}
Summary: A 5 years old, spayed domestic short-hair cat presented because of difficulty opening the mouth and loss of appetite. A firm-swelling was found on her left temporal area. The cat was FeLV negative. Surgical exploration was performed for biopsy and volume reduction. The pathological diagnosis was osteochondroma. The tumor could not be removed completely at two additional surgeries. Fifty-three months after the first surgery, remaining tumor growth decelerated, which was accompanied by the appearance of radio-transparent areas inside of the tumor. The long axis of the tumor increased about $1.3 \mathrm{~mm}$ during the final 59 months. The tumor remained in her left temporal area for more than 10 years; the cat continued to be able to eat normally. She died of unknown causes at 16 years of age, with no obvious metastasis and/or acute growth.
\end{abstract}

Key words: feline, solitary osteochondroma, palliative surgery

要約：5歳、日本猫、避妊済みの雌猫が食欲不振と開口障害を主訴に来院した。一般身体検査で、左側頭部に硬性の腫瘤性 病変を認め、FeLV検査は陰性であった。その腫瘤性病変に対し、診断と減容積を目的とする切除生検を行い、骨軟骨腫と 病理組織診断された。その後、2回の外科的切除を実施したが、完全切除には至らず、開口障害の改善にとどまった。切除 生検後 53 ヶ月目から腫瘍病変の増大速度の低下とレントゲン透過性の元進像が認められ、最後の 59 ヶ月間では $1.3 \mathrm{~mm} の$ 増大にとどまった。16歳時に骨軟骨腫とは別の要因により死亡した。約 10 年間の長期的経過観察中、腫瘍は存在したもの の、転移はなく、開口障害もなく、通常の摂食行動が可能であった。

キーワード : 猫、孤立性骨軟骨腫、緩和的外科的切除

Jpn. J. Vet. Anesth. Surg. 51(3\&4): 52-57, 2020.

Introduction

Osteochondromas are cartilage-capped benign bony tumors arising from the external bone surface, continuous with that of the underlying bone ${ }^{9,10}$.

\footnotetext{
1) 小儀動物病院（广564-0024 大阪府吹田市高城町 17-3）

2) 茨木元町どうぶつ病院（干 567-0882 大阪府茨木市元町 6-30）

${ }^{3)}$ Vettec Dentistry（干131-0032 東京都墨田区向島3 丁目20-7）

*Corresponding author: Jun MATSUMOTO,

E-mail: sora-iigo-benkei@hotmail.co.jp
}

受付日 2020 年 8 月 5 日 受理日 2020 年 11 月 14 日
Osteochondromas can be solitary (monostotic) or multiple (polyostotic). Although they have rarely been reported converting to malignancy, especially if polyostotic and presenting at a relatively older age $^{1,2,4,9,10)}$, prognosis of the polyostotic type in all species reported is generally poor ${ }^{9}$. Osteochondromas develops commonly at the endochondral areas of long bones in humans, dogs, pigs and horses early in life, but the osteochondromas in cats develops long bone as well as skull bones continuously later age in life ${ }^{9,10,12)}$. In domestic cats, the tumor, commonly called feline osteochondomatosis, presents 
as multiple progressive lesions at 2-3 years of age, and has been linked with feline leukemia virus

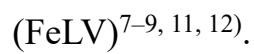

\section{Case Report}

A 5 years old, spayed domestic short-hair cat presented with difficulty opening the mouth and loss of appetite. A firm-swelling was palpated on the left temporal area. While conscious, the mouth could not be opened fully. On physical examination, the cat was normal except for the temporal mass and inability to examine the mouth. Complete blood count (CBC) and serum chemistry tests were within normal limits except for high alkaline phosphatase level (290 IU/1). Feline immunodeficiency virus (FIV) and FeLV tests were negative. Serum thyroid hormone level was within the normal range. Chest radiographs were normal.

Under sedation [by isofluren (Isoflurane Inhalation Solution, Pfizer, Tokyo, Japan) with induction chamber], the mouth could be opened no further than when the cat was not sedated. On radiographs of the head, a large highly opaque lesion was found affecting the coronoid process of the left mandibular ramus, spreading to the zygomatic arch (Fig. 1); the lesion was unevenly opaque. The limited jaw move- ment was caused by the coronoid process lesion.

Under general anesthesia by isofluren with intubation after premedicated by $0.01 \mathrm{mg} / \mathrm{kg}$ glycopyrrolate (Robinul, Aspen, Sydney, Australia) and $0.2 \mathrm{mg} / \mathrm{kg}$ butorphanol (Vetorphale, Meiji Seika Pharma, Tokyo, Japan) and with isofluren in an induction chamber, surgical exploration was performed for biopsy and volume reduction. The nodular lesion was removed progressively until the jaw was able to be opened fully and was submitted for pathological examination (Fig. 2). Following surgery, the cat could open her mouth, and had a normal appetite. Mandibular shift to the left was seen 2 weeks after the 1 st surgery.

The histopathological diagnosis (Hist Vet. Inc, Kanagawa, Japan) was osteochondroma with proliferation of bone and cartilage tissues; there was no evidence of malignancy or obvious mitosis (Fig. 3).

The zygomatic arch, mandibular ramus, condylar process and caudal part of the horizontal ramus of the left mandible were resected palliatively one month after the 1st surgery for maintaining quality of life (QOL). The lesion could not be completely removed because of its extension medially (Fig. 4). Complete crawn amputation without endodontic treatment and covered by gingiva was performed on mandibular canine teeth by preventing occlusal trauma caused by jaw shift and stage 3 of type II resorptive lesions.
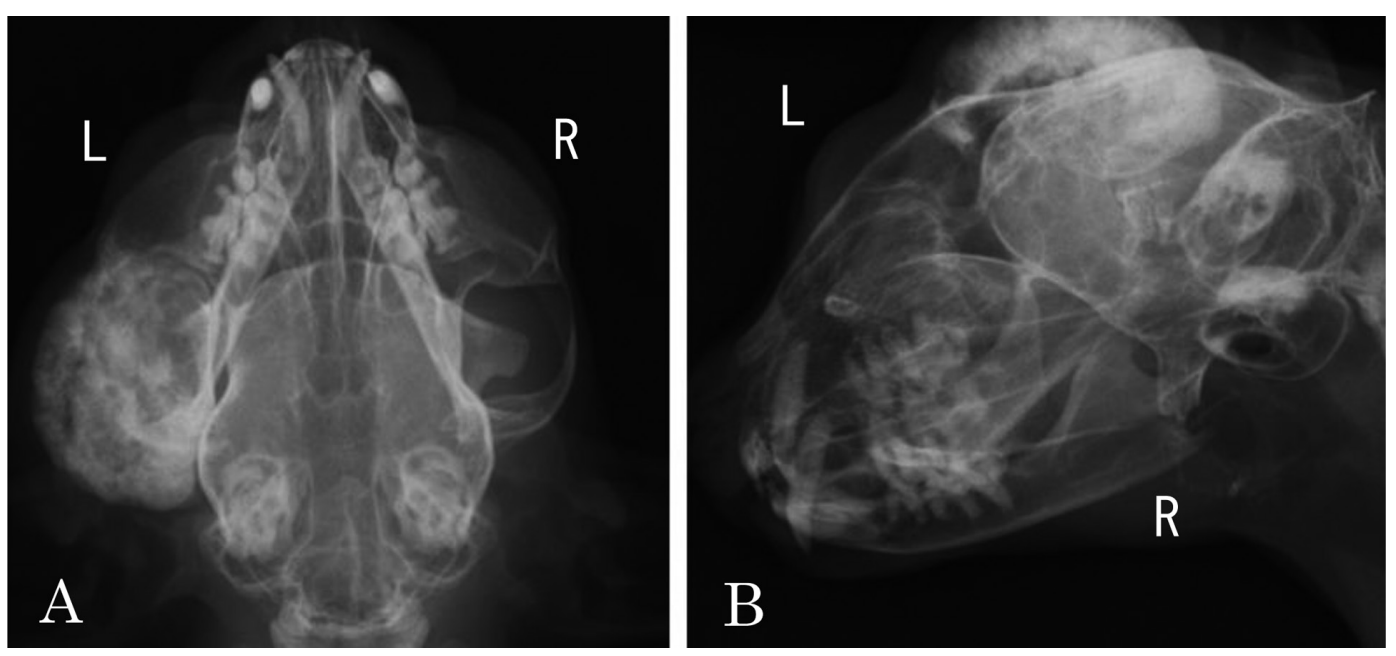

Fig. 1. Preoperative radiographs. (A) Head DV image shows calcified mass on the left mandibular ramus extending laterally and distally. The long axis of the calcified mass measured $35 \mathrm{~mm}$. (B) Head slightly oblique lateral image. 


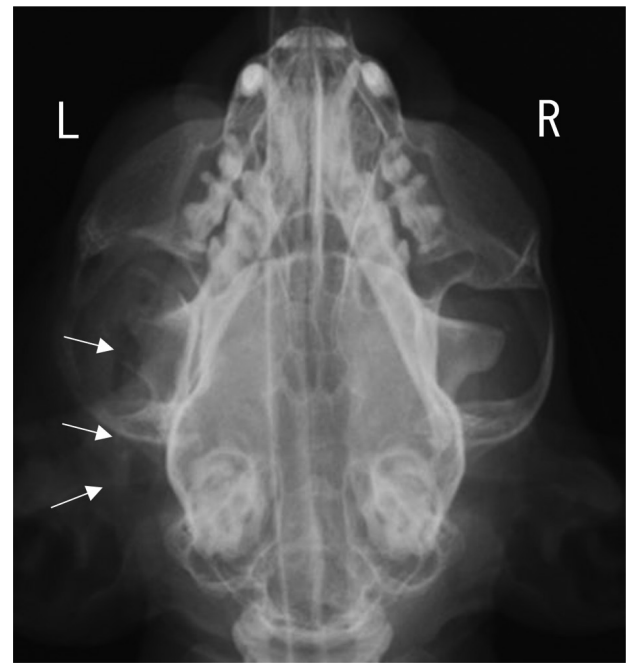

Fig. 2. Head DV radiograph immediately after the first surgery for biopsy and volume reduction. Some calcified lesions (white arrows) remain dorsal to the left mandibular ramus and around the left TMJ.

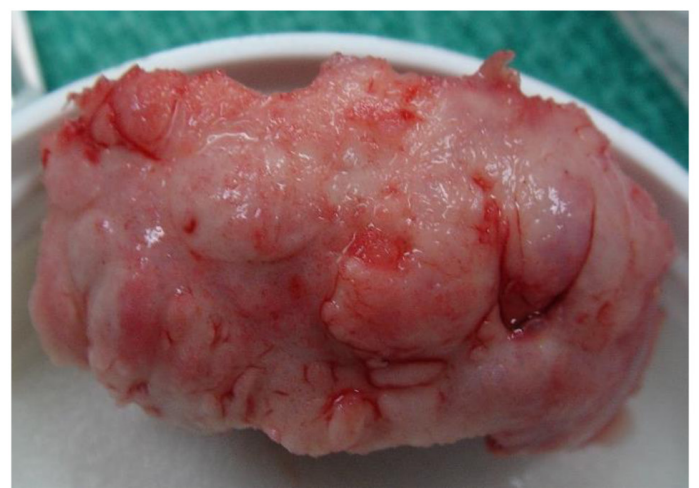

A

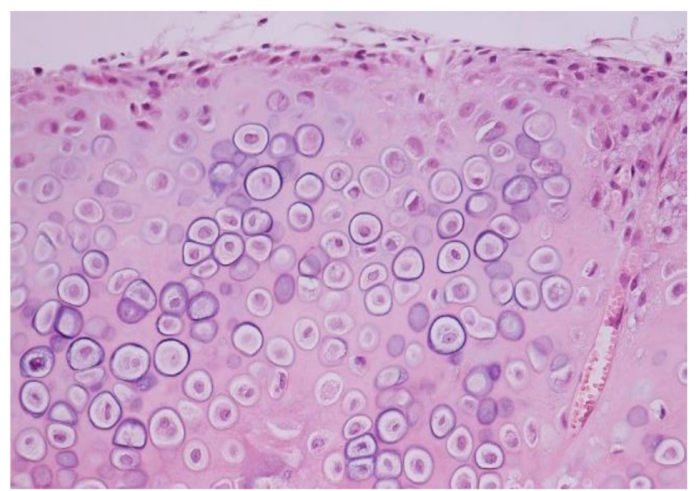

B-1

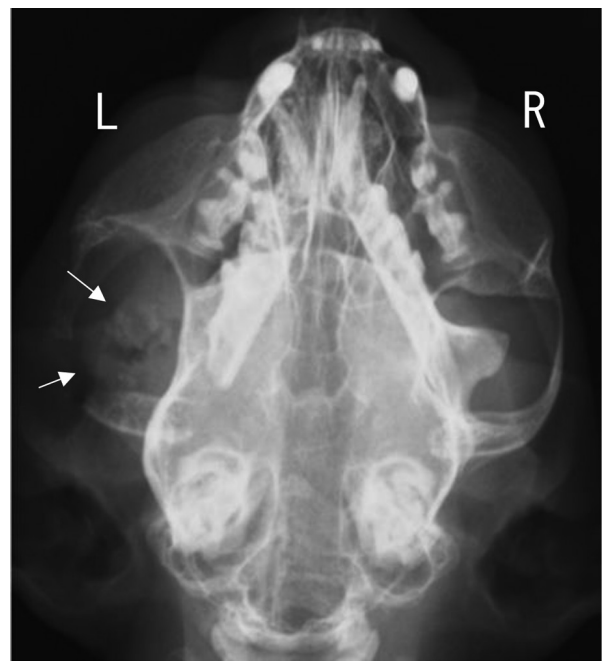

Fig. 4. Head DV radiograph after second surgery, at which the center of the zygomatic arch, the mandibular ramus, the condylar process and the caudal part of the mandibular body were removed. Some lesional tissue (white arrow) remains.

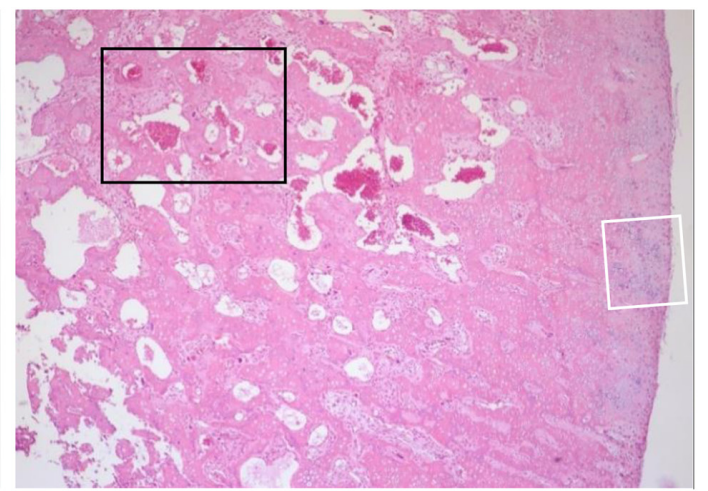

B

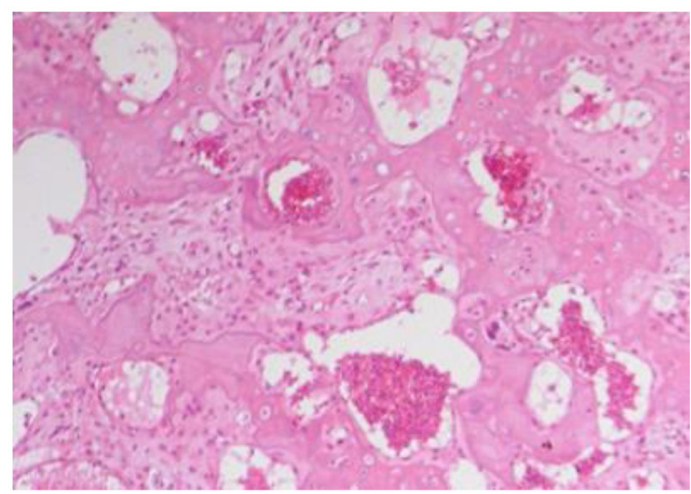

B-2

Fig. 3. Part of mass removed at the first surgery. (A) The mass had a hard nodular surface.

(B) Histopathology of the mass surface at low-magnified field (HE $\times 40)$. B-1 (white square in B): Surface of the mass covered by cartilage that is growing $(\mathrm{HE} \times 200)$. B-2 (black square in B): The center of the mass consisted by bony tissue with growing cartilage undergoing growth. These histological images are similar to those seen in endochondral ossification $(\mathrm{HE} \times 200)$. 
The histopathology was the same as the first sample; mature bone was arranged in an irregular proliferative palisade formation or as islands of bone and cartilage tissue; no mitosis was observed on the sample slides.

Three months after the first surgery, the lesional tissue left in the temporal area had gradually extended, though the mouth was still able to open normally. Eighteen months after the first surgery, growth of the mass had displaced the left eyeball rostrally. Palliative surgery was again performed to reduce the volume of the mass palliatively (Fig. 5). Further coronal reduction was performed to relief soft tissue pain from occlusal trauma. The cat ate normally and was playful.

No further treatment was provided because of the owner's request. The maxillofacial area was palpated and radiographed every 6 months. The tumor continued to enlarge slowly; it was $12 \mathrm{~mm}$ on its long axis, with radiological transparency at the center of the tumor 45 months after the first surgery. The radiologically transparent zone inside the lesion gradually enlarged, and growth of the tumor decelerated (Fig. 6); the lesion at the final measurement,

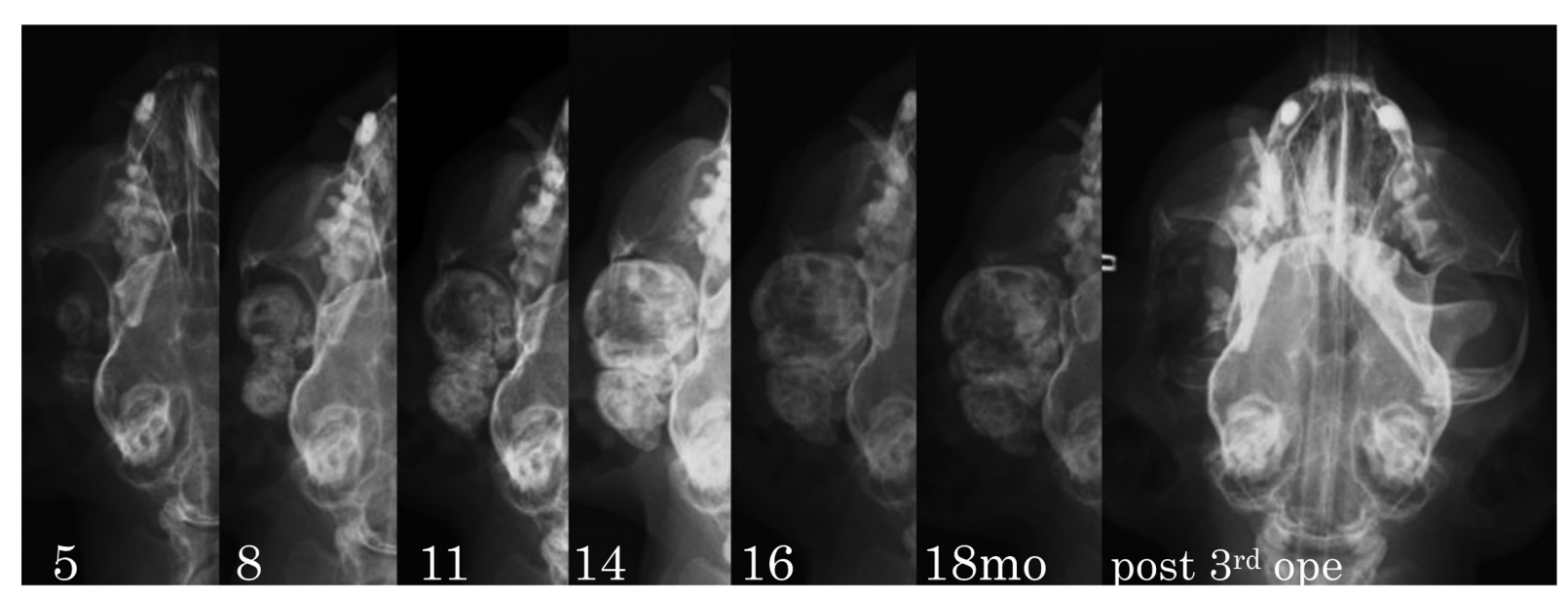

Fig. 5. The radiological changes of the lesion size over time from 5 months after first surgery to the third surgery.

(The numbers on the radiographs are months after the first surgery.)

The lesion gradually extended during the first 13 months. At 18 months, the long axis of the lesion was about $30 \mathrm{~mm}$ and was displacing the eyeball. Further palliative surgery $\mathrm{f}$ was performed, but the lesion was not completely removed.

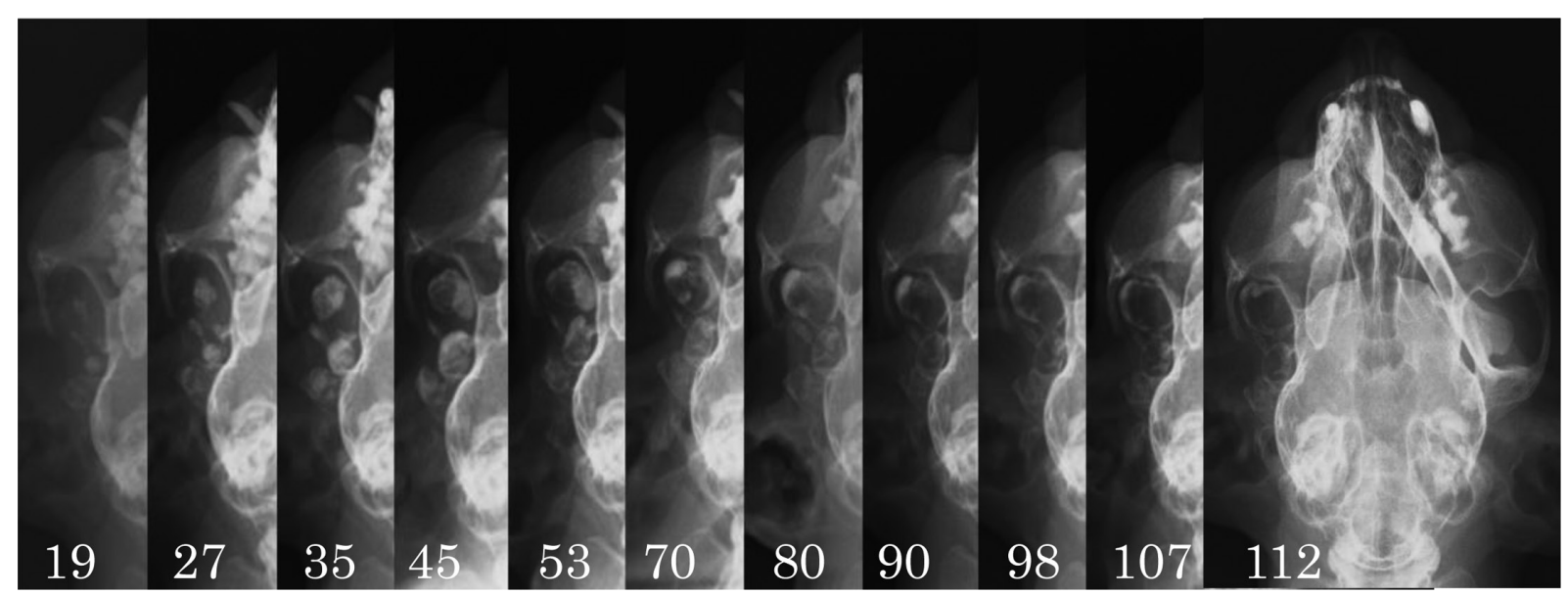

Fig. 6. The radiological changes of the lesion size over time from 19 months after first surgery to 112 months. (The numbers on the radiographs are months after the first surgery.)

The growth rate of the lesion was slow from the time of the third surgery and a transparent zone is seen in the center of the lesion 45 months after the first surgery. The transparent zone grew larger over time. 


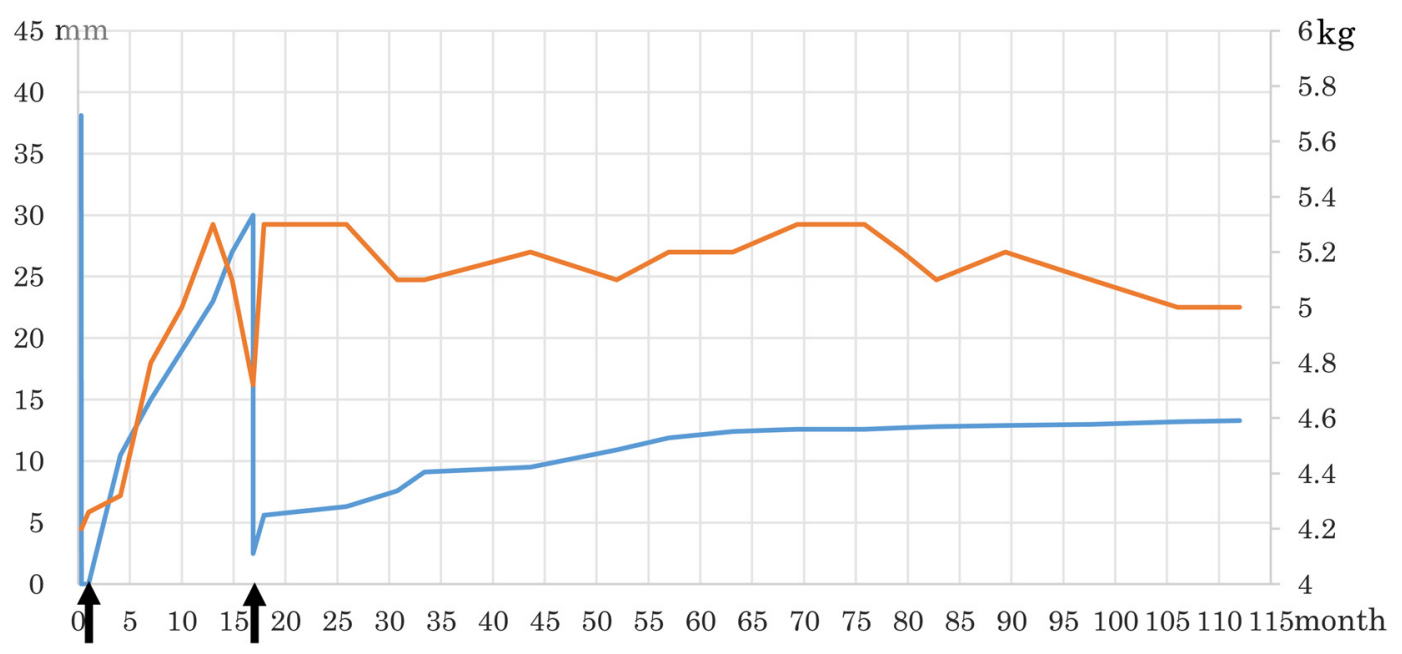

Fig. 7. The long axis of the lesion (blue line) left over time with her body weight (red line). (The numbers on the horizontal axis are months after the first surgery with black arrows of 2nd and 3rd surgery respectively. The numbers on the left vertical axis are the length of the longitudinal axis in mm while the numbers on the right vertical axis are body weight in $\mathrm{kg}$.) The size of lesion increased rapidly from 5 months to 18 months, then growth slowed after the third surgery and was much slower after 55 months. The body weight had kept constantly after the third surgery.

112 months after the first surgery, was $13.3 \mathrm{~mm}$ radiographically; it had grown only $1.3 \mathrm{~mm}$ during the final 59 months. During observation of her health condition with tumor size, her body weight was kept constantly after palliative surgeries (Fig. 7).

Her health status had been in normal except for cystitis, with no evident renal disease until the cat's death from unknown causes at 16 years of age (136 months after the first surgery). When her last visit was 123 months after the first surgery, blood tests (CBC and general biochemical tests) and chest radiographs were in all normal range. The owner reported the cat's death by phone; the owner noted that there were no visible changes in the maxillofacial area since the previous examination.

\section{Discussion}

Biological behaviors, growth, and metastasis of osteochondoroma in all animal species are nonspecific $^{9}$. The histopathological features of solitary and multiple osteochondromas indistinguishable. Feline osteochondromatosis, a multiple osteochondroma, differs from the osteochondroma in dogs and horses in its clinical setting, skeletal distribution, histopathological features and prognosis ${ }^{9}$. The feline disorder may develop either from endochondral ossification beneath a cap of cartilage, as in dogs and horses, or directly from the overlying periosteum ${ }^{1,7,9)}$. A solitary osteochondroma was reported in a FeLV positive $\mathrm{cat}^{8)}$; although benign, the lesion progressively expanded ${ }^{9}$. A possible association with FeLV has been reported. The condition has been reported in two FeLV negative cats ${ }^{3,6)}$; however; the reported histopathological description appeared more similar to progressive fibrodysplasia ossificans than osteochondoroma ${ }^{9}$.

The case presented here had FeLV negative serology, a solitary lesion in the area of the zygomatic arch and mandibular ramus which form by membranous ossification $^{5)}$, and had no metastasis. The transparency changes seen on the later radiographs were not examined histopathologically.

Previous reviews reported that osteochondoroma in cats shows progressive enlargement after skeletal maturity, but this case was observed slow enlargement with aging $9,10,12$ ). It is suggested that several palliative surgeries helped the cat live longer with maintaining QOL. 


\section{Acknowledgment}

We appreciate the critical reading and helpful comments from Colin E Harvey, BVSc, FRCVS, DipACVS, DipAVDC.

\section{References}

1) Doige, C. E. (1987): Multiple Osteochondromas with evidence of malignant transformation in a cat. Vet. Pathol. 24: 457-459.

2) Green, E. M., Adams, W. M., and Steinberg, H. (1999): Malignant transformation of solitary spinal osteochondroma in two mature dogs. Vet. Radiol. Ultrasound. 40: 634-637.

3) Levitin, B., Arloch, I., Aizenberg, I., Foreman, O., and Shmir, M. (2003): Linear osteochondromtosis in a cat. Vet. Radiol. Ultrasound. 44: 660-664.

4) Murphey, M. D., Choi, J. J., Kransdorf, M. J., Flemming, D. J., and Gannon, F. H. (2000): Imaging of osteochondroma: variants and complications with radiologic and pathologic correlation. Radiographics. 20: 1407-1434.

5) Noden, D. M., and De Lahunta, A. (1985): Craniofacial skeleto- genesis. In: The Embryology of Domestic Animals, pp. 181186, Williams \& Wilkins, Baltimore.

6) Nolff, M. F., Puff, C., Langer, B., and Fehr, M. (2014): Feline osteochondromatosis in a FELV-negative European shorthair cat. Tierarztl. Prax. 42(1): 55-59.

7) Pool, R. R., and Carrig, C. B. (1972): Multiple cartilaginous exostoses in a cat. Vet. Path. 9: 350-359.

8) Rosa, C., and Kirberger, R. M. (2012): Extraskeletal osteochondroma on a cats elbow. J. S. Afr. Vet. Med. Assoc. 83: 1-4.

9) Thompson, K. G., and Dittmer, K. E. (2017): Benign tumors of bones. In Tumors in Domestic Animals, 5th ed, by Meuten DJ, pp. 359-371, Wiley Blackwell, Ames.

10) Toner, M., and van Heerden WFP (2017): Osteochondroma, benign maxillofacial bone and cartilage tumours in WHO classification of head and neck tumors, (El-Naggar, A. K., Chan, J. K. C., Grandis, J. R., Takata, T., Slootweg, P. J., ed.) p. 255, WHO.

11) Turrel, J. M., and Pool, R. R. (1982): Primary bone tumors in the cat. A retrospective study of 15 cats and literature review. Vet. Radiol. 23: 152-166.

12) Voss, K. (2009): Disease of bone. In: Feline Orthopedic Surgery and Musculoskeletal Disease (Montavon, P. M., Voss, K., and Langley-Hobbs, S. J. ed.) pp. 60-62. Elsevier, Philadelphia. 